\title{
Human resources planning and auditing in agribusiness
}

\author{
Alsou Zakirova ${ }^{1,}{ }^{*}$, Guzaliya Klychova $^{1}$, Alfiya Yusupova $^{2}$, Valeriya Kirillova ${ }^{3}$ and Ildus \\ Gimadiev ${ }^{1}$ \\ ${ }^{1}$ The State Agrarian University of Kazan, Department of Accounting and Audit, 420015 Kazan, \\ Russia \\ ${ }^{2}$ Russian Islamic Institute, 420049 Kazan, Russia \\ ${ }^{3}$ Academy of Social Education, 420039 Kazan, Russia
}

\begin{abstract}
Human resources and their development exert a considerable impact upon the effectiveness of an enterprises focused on innovative development since the potential of the personnel, its proper management and assessment provide competitiveness, strategic advantages and sustainable growth of the agricultural sector of any economy. To achieve the end goals an organization management must be guided by the rational use of not only financial and material resources but labor force as well. At the same time, workforce management appears to be one of the important areas of strategic development as, in an innovative economy the level of proficiency, knowledge, abilities and competence of an employee, become increasingly demanding. The article presents the procedure for planning personnel audit in accordance with international standards and provides precise matter making possible to be aware of the audit mechanism at the level of a particular economic entity. By means of applying such general scientific techniques as systematic approach, comparative analysis, classification and information integtating the authors have got an insight into the main principles of planning $\mathrm{HR}$ audit and scrutinised new requirements for the planning process in view of the fact that the international standards have become effective. With this in view the authors have elaborated the auditor's working documents making possible to improve the efficiency of personnel audit and coordinate audit procedures with the work of the audited entity's personnel.
\end{abstract}

\section{Introduction}

In the current context, to most effectively use the employees' capabilities, to create conditions for the personnel being engaged in earnest and intensive development of their potential, it is necessary to ensure optimal interaction of staff and the organization, as well as their relationship with the external environment. Competitive struggle and rapidly changing global situation force the enterprises to be focused on the internal state of affairs and strive to develop a long-term strategy offering a means to quickly respond to the changes.

\footnotetext{
* Corresponding author: kgaukgs@mail.ru
} 
Any economic entity is at liberty to choose management methods taking into account the restrictions imposed by the external environment [4, 7]. Developing a device and system of human resources management, it is necessary to ensure social-economic development having concurrently solved the following tasks: to form a management structure highlighting its main elements and their relationship; to define a list of rights and obligations of the economic entities; to elaborate, test and evaluate the most rational systems and forms of organization and labour remuneration. And that is where personnel audit holds a specific place.

Personnel audit is a set of methods and principles for the emplyee's compliance with their organization's goals and objectives to be independently verified; it is the assessment of achievements in the field of knowledge management, the evaluation of the coworkers' personal potential, probe into the staffing structure operations aimed at identifying discrepancies and eliminating inconsistencies in the financial and economic activities of the company.

The object of the personnel audit lies in diagnostics of the existing personnel policy in the economic entity being audited, the assessment of its impact on the system of tactical and strategic management in industrial, social and economic activities;an effort to elaborate a set of measures aimed at eliminating the shortcomings identified.

Personnel audit is a sustainable system that comprises various characteristic procedures, technologies, methods of analysis and solution of specific problems.

\section{Materials and Methods}

Human resources audit planning should be carried out in accordance with the International Auditing Standard 300 " Plan making in financial statements audit". According to the Standard, before starting work each human resources auditor should make sure to the extent practicable that it's worth to continue the relationship with the client and perform the audit task.

In compliance with International Auditing Standard 220 "Quality Control At Financial Statements Auditing" a human resources auditor should be bound by the following conditions:

- seamless interaction based on honesty, mutual trust and respect [9] with owners, key managers and persons who are responsible for corporate governance, regarding the most significant issues at all stages of personnel audit;

- competent employees in the audit team and all necessary resources making possible to effectively perform the task; to obtain sufficient and necessary consultations of various experts at all stages of the personnel audit [8];

- compliance with the requirements of ethic both by the audit team and the organization under audit,

- the ability to assess significant issues arising in the course of the audit assignment executing, particularly documentation maintenance since it records the results of the work done and decisions made at all stages of personnel audit; compliance with the audit techniques, approved rules, procedures and recommendations.

Human resources auditor must be also certain that the client has a clear understanding of the goals, objectives and nature of the work to be done and agrees with the audit team's interpretation of the audit assignment.

After having completed the above procedures the auditor enters upon developing an overall strategy and plan of personnel audit.

In compliance with paragraph 7 of the International Auditing Standard 300 the general audit strategy should reflect the scope, purposefulness and timing of the personnel audit and be the basis of the audit plan. 
Developing a strategy of personnel audit the auditor shall identify those features of the audit assignment which are key to its scope and confirm the reporting targets according to the audit assignment while planning the timing of the personnel audit and determining the type of information interaction. To make the audit group activities more purposeful the auditor should also analyze the factors that, in his/her opinion are particularly important and examine the results of the work carried out previously according to audit assignment. A competent auditor establishes the pattern, scope and terms of exploiting the resources necessary for personnel audit; defines the list of audit procedures and methodological support of their application $[1,10]$.

The main form of documentation for the overall HR audit strategy is the recording of key decisions that are required when properly planning an audit and bringing key issues to the notice of the audit team members. The overall audit strategy may be submitted in the form of a Memorandum that contains the decisions on the scope, timing and order of audit implementation [12, 18, 19].

Having completed the elaboration of the overall audit strategy the auditor proceeds to planning HR audit that implies solving the problems stated in the general audit policy. With this in view account must be taken of the necessity to achieve the main goals of audit by means of utilizing the resources available at the audit organization.

The personnel audit plan describes the type, timing and scope of the planned procedures being performed by members of the audit team $[2,11]$. Audit procedures are planned within the process of elaborating the strategy throughout the HR audit.

In compliance with International Audit Standard 300 the audit plan should reflect the prearranged pattern, timing and scope of risk assessment procedures and subsequent audit measures at the prerequisite level in response to the assessed risks. In this case the auditor may use standard audit programs or checklists drawn up taking into account certain circumstances of the audit assignment.

The overall strategy of the HR audit plan is closely interrelated and, as a consequence, changes in one document lead to the need to make appropriate changes in another.

Witin the audit process various unexpected events, changes in circumstances and evidences collected in the process of conducting audit procedures [3, 14] may take place. As a result, the auditor needs to make changes to the overall strategy and audit plan, and, consequently, to the pattern, timing and scope of subsequent audit procedures. That most often happens because the auditor receives data that significantly differ from those that were available during the initial planning of the relevant audit procedures $[5,16]$.

Significant changes in the overall audit strategy and plan as well as the resulting changes in the planned timing, scope and pattern of the audit procedures must be reflected in documents explaining the reasons for these considerable changes. The documents must also reflect the appropriate measures in response to such measurable changes that occur in the process of personnel audit.

To effectively execute the auditor's assignment the HR auditor may discuss certain aspects of planning with a corporate management team under audit $[6,15]$. However, when discussing issues related to the overall strategy and personnel audit plan, the auditor should think of not putting in jeopardy their effectiveness.

\section{Results}

The audit plan in accordance with the requirements of IAS 300 "Plan Making In Financial Statements Audit" should comprise the following sections:

1. Comprehension of business implies a description of the general economic factors and conditions in the industry that affect the economic operations of the audited entity as well 
as the important characteristics of the entity; the results of financial and economic activities and reporting requirements including the overall level of management competence $[16,17]$.

For example, in a personnel audit, the subject of discussion and the auditor's actions may be reflected in the description of the audited organization's activities (Table 1).

Table 1. Comprehension of the auted organization business activities.

\begin{tabular}{|c|c|}
\hline Subject of Discussion & Auditor's Actions \\
\hline \multicolumn{2}{|c|}{ Assessment of management structure and system } \\
\hline $\begin{array}{l}\text { Assessment of mission, strategy and } \\
\text { goals of the organization }\end{array}$ & $\begin{array}{l}\text { We will assess the availability and coherence of the } \\
\text { organization's mission, strategy, goals and current } \\
\text { objectives. }\end{array}$ \\
\hline $\begin{array}{l}\text { Evaluation of subordinates ' executiing } \\
\text { management decisions }\end{array}$ & $\begin{array}{l}\text { We will analyze the content and the number of } \\
\text { decisions that are not implemented but being } \\
\text { reviewed and require further elaboration }\end{array}$ \\
\hline $\begin{array}{l}\text { Assessment of the organizational } \\
\text { structure compliance with current } \\
\text { economic environment }\end{array}$ & $\begin{array}{l}\text { We will determine the availability or lack of the } \\
\text { structure domination over the function, } \\
\text { bureaucratization, stagnation, duplication of the } \\
\text { organizational order. }\end{array}$ \\
\hline \multicolumn{2}{|l|}{ Personnel performance assessment } \\
\hline $\begin{array}{l}\text { Assessment of the employee's } \\
\text { professional and innovative potential }\end{array}$ & $\begin{array}{l}\text { We will assess the employees' ability to make } \\
\text { unconventional and nonroutine decisions as well as } \\
\text { their ability of professional growth }\end{array}$ \\
\hline $\begin{array}{l}\text { Assessment of the employee's } \\
\text { performance and excess activity }\end{array}$ & $\begin{array}{l}\text { We will assess the ability to perform a larger amount } \\
\text { of work than it is established by the Manager. }\end{array}$ \\
\hline $\begin{array}{l}\text { Assessment of the ability to work in a } \\
\text { group and perform management activities }\end{array}$ & $\begin{array}{l}\text { It is assumed to assess the employee's leadership } \\
\text { qualities, sociability, proneness to conflict, level of } \\
\text { culture and role in the group. }\end{array}$ \\
\hline \multicolumn{2}{|c|}{ Assessment of HR policy, professional skills and performance of HR specialists } \\
\hline Workforce planning assessment & $\begin{array}{l}\text { We will assess the availability of programs to attract } \\
\text { and train personnel, the availability of methods for } \\
\text { calculating the required number of employees } \\
\text { according to category as well as working with the } \\
\text { personnel reserve. }\end{array}$ \\
\hline $\begin{array}{l}\text { Assessment of the availability and the } \\
\text { development level in the motivation and } \\
\text { incentive system }\end{array}$ & $\begin{array}{l}\text { We analyze the structure of wages, the share of } \\
\text { bonuses therein and determine whether there are } \\
\text { schemes that personify payments depending on the } \\
\text { efficiency of activities; then assess whether the } \\
\text { elaborated principles, the structure of wages and } \\
\text { benefits for productivity and profitability of } \\
\text { activities comply with conditions existing in the } \\
\text { labor market. }\end{array}$ \\
\hline Evaluation of personnel training system & $\begin{array}{l}\text { We will study and evaluate the system of the } \\
\text { employees' retraining, training and advanced } \\
\text { training in terms of costs, practical orientation of } \\
\text { training programs, the results of employees who } \\
\text { have already passed through such instruction and } \\
\text { changes in the social-psychological climate and } \\
\text { motivation to work. }\end{array}$ \\
\hline
\end{tabular}


2. Comprehension of business environment and internal control consisting in the process of accounting policy and its changes review; determining the impact of new accounting and auditing standards; accumulation of the auditor's scope of knowledge concerning the systems of accounting and internal audit; establishment of control valid tests and verification procedures.

3. Description of risk and materiality, particularly the expected risk assessment of the control system and determination of the main audit directions; materiality level detection; the probability of material misstatements and fraud within the past periods; identification of problem areas of accounting including those related to valuation knowledge; focus on specific areas of audit; the impact of information technology on audit; internal audit service functioning and its expected impact on external audit. An example of a significant risk that is applicable to the personnel audit in accordance with IAS is given in Table 2 .

Table 2. Risks of material misstatement.

\begin{tabular}{|c|c|c|}
\hline $\begin{array}{l}\text { Noteworthy } \\
\text { Risk }\end{array}$ & Description & Substantive Audit Procedure \\
\hline $\begin{array}{l}\text { Imposition of } \\
\text { penalties on a } \\
\text { legal entity as a } \\
\text { result of } \\
\text { improper } \\
\text { registration of } \\
\text { the right to sign } \\
\text { personnel } \\
\text { documents } \\
\text { what entails a } \\
\text { significant } \\
\text { increase in } \\
\text { risks including } \\
\text { financial ones. }\end{array}$ & $\begin{array}{l}\text { The labour code regulates the } \\
\text { consequences that arise as a result of the } \\
\text { actual work permit given for a person } \\
\text { not duly authorized thereunto. } \\
\text { In case an individual admitted to work } \\
\text { by a person not duly authorized } \\
\text { thereunto by the employer, repudates the } \\
\text { relationship to be labor-management } \\
\text { relations then the employer for whom } \\
\text { such work was executed, must make } \\
\text { payments to that individual for } \\
\text { hours actually worked or the work } \\
\text { performed. } \\
\text { This assumption can be refuted in case } \\
\text { the auditor has come to realize that there } \\
\text { is no risk of material misstatement due } \\
\text { to erroneous actions of the human } \\
\text { resources service. }\end{array}$ & $\begin{array}{l}\text { Consideration of the risk factors set } \\
\text { out in International Auditing } \\
\text { Standard } 240 \text { makes possible to } \\
\text { leads to the conclude that the risk } \\
\text { of penalties may be rejected } \\
\text { because: } \\
\text { - it is envisaged that the person } \\
\text { authorized to sign on certain } \\
\text { personnel documents will be bound } \\
\text { by the appropriate responsibility; } \\
\text { - the employment contract and job } \\
\text { description of the authorized } \\
\text { official are amended in relation to } \\
\text { the change of their labor functions } \\
\text { and the additional powers } \\
\text { imposition; } \\
\text { - an explicit list of documents } \\
\text { where an authorized official is } \\
\text { entitled to sign, is worked out and } \\
\text { clearly defined. }\end{array}$ \\
\hline
\end{tabular}

4. Description of the pattern, terms and scope of the audit procedures.

Based on the overall audit strategy the audit group head works out a personnel auditing plan that indicates the amount of work to be done; the main activities of the enterprise under audit; sections of social-economic and other reporting subject to be examined and analyzed; methods and techniques of verification for each work site; deadlines; allocation of personnel auditors' duties; as well as proforma working papers and the order of their registration.

\section{Discussion}

The audit plan details all the procedures that are necessary to implement the HR audit strategy. The need for such plan detailed elaboration is stipulated by the fact of its being substantively an instruction to the auditors. Moreover, the plan is a basic document that makes possible to monitor the auditors' execution of their tasks since it determines the number of auditors required as well as the amount and content of their work. When developing a plan for personnel audit and determining its methods, it should be noted that the audit proce- 
dures should help to identify the availability of material misstatements and inconsistencies in social-economic indicators.

Proceeding with a personnel audit plan (Table 3) the auditor should determine the following: which cases are subject to audit procedures, i.e. substantive audit procedure and where it is permissible to make just audit sample.

The timing of the personnel audit is influenced by the number of specialists included in the team, their qualifications, technologies and methods applied as well as the total amount of work.

Table 3. HR auditing plan (fragment).

\begin{tabular}{|l|l|}
\hline Audited entity name & LLC "Pravda" \\
\hline Auditing period & March 14. 2017- March 24. 2017 \\
\hline The scope of auditing (man-hour) & 156 \\
\hline Audit team head & Nikiforov A. V. \\
\hline Audit team members & $\begin{array}{l}\text { Simonov V.V., Feofanova G.P., Platonova } \\
\text { N.G. }\end{array}$ \\
\hline Planned level of materiality & 8463 thous. rubles \\
\hline Planned audit risk & $4 \%$ \\
\hline
\end{tabular}

Table 4. HR auditing plan (fragment).

\begin{tabular}{|c|c|c|c|}
\hline No & $\begin{array}{l}\text { The list of audit services in the } \\
\text { areas of personnel audit }\end{array}$ & Methodological tools & $\begin{array}{l}\text { Auditor's } \quad \text { working } \\
\text { documents }\end{array}$ \\
\hline \multicolumn{4}{|c|}{ Audit of HR recordkeeping: } \\
\hline 1.1 . & $\begin{array}{l}\text { Audit of structure, staff list } \\
\text { and staff deployment }\end{array}$ & $\begin{array}{l}\text { Expert assessment of } \\
\text { documentation } \\
\text { compliance with the } \\
\text { legislation }\end{array}$ & $\begin{array}{l}\text { Summary statement of } \\
\text { violations revealed } \\
\text { according to audit check }\end{array}$ \\
\hline 1.2 . & $\begin{array}{l}\text { Audit of mandatory and addi- } \\
\text { tional local regulations con- } \\
\text { tent and execution }\end{array}$ & $\begin{array}{l}\text { Checking the availability } \\
\text { of necessary } \\
\text { documentation; expert } \\
\text { assessment } \\
\text { documentation } \\
\text { compliance with the } \\
\text { legislation }\end{array}$ & $\begin{array}{l}\text { Summary statement of } \\
\text { violations revealed } \\
\text { according to audit check }\end{array}$ \\
\hline \multicolumn{4}{|c|}{ 2. Audit of HR record management } \\
\hline 2.1 . & $\begin{array}{l}\text { Verification of employment } \\
\text { contracts with employees: } \\
\text { availability, registration, } \\
\text { content (conditions) }\end{array}$ & 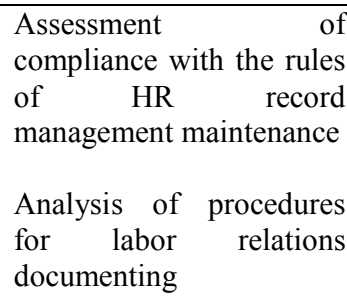 & $\begin{array}{l}\text { Summary statement of } \\
\text { violations revealed } \\
\text { according to audit check }\end{array}$ \\
\hline 2.2 . & $\begin{array}{l}\text { Validation of staff orders: } \\
\text { the correctness of their issu- } \\
\text { ing; compliance with dead- } \\
\text { lines of their review by the } \\
\text { employees; terms of their } \\
\text { registration and retention }\end{array}$ & $\begin{array}{l}\text { Inspection and } \\
\text { examination of orders; the } \\
\text { documents desktop } \\
\text { review }\end{array}$ & $\begin{array}{l}\text { Summary statement of } \\
\text { violations revealed } \\
\text { according to audit check }\end{array}$ \\
\hline
\end{tabular}




\begin{tabular}{|c|c|c|c|}
\hline \multicolumn{4}{|c|}{ 3. Assessment of compliance with the Labour Code } \\
\hline 3.1 & $\begin{array}{l}\text { Assessment of compliance } \\
\text { with recruitment constraints }\end{array}$ & $\begin{array}{lrr}\text { Assessment } & \text { of } \\
\text { compliance with } & \text { the } \\
\begin{array}{l}\text { Labour Code, } \\
\text { documents }\end{array} & \text { the } \\
\text { assessment } & & \text { legal } \\
\end{array}$ & $\begin{array}{l}\text { Certificate of auditing } \\
\text { results }\end{array}$ \\
\hline 3.2 & $\begin{array}{l}\text { Assessment of compliance } \\
\text { with the employer's and } \\
\text { workers' labour rights and } \\
\text { duties: the mode of work and } \\
\text { rest, overtime, work on days } \\
\text { off; remuneration of work; } \\
\text { guarantees and compensa- } \\
\text { tions; granting of leaves, etc. }\end{array}$ & $\begin{array}{lrr}\text { Assessment } & \text { of } \\
\text { compliance with } & \text { the } \\
\text { Labour Code, } & \text { the } \\
\text { documents } & & \text { legal } \\
\text { assessment } & & \end{array}$ & $\begin{array}{l}\text { Certificate of auditing } \\
\text { results }\end{array}$ \\
\hline \multicolumn{4}{|c|}{ 4. Audit of personnel activities } \\
\hline 4.1. & $\begin{array}{l}\text { Verification of the employees' } \\
\text { proficiency, their professional } \\
\text { and innovative potential }\end{array}$ & $\begin{array}{l}\text { matrix method, } \\
\text { the method of scoring, } \\
\text { method of arbitrary } \\
\text { characteristics system }\end{array}$ & $\begin{array}{l}\text { Summary statement of } \\
\text { violations revealed } \\
\text { according to audit check }\end{array}$ \\
\hline 4.2. & $\begin{array}{l}\text { Testing an employee's apti- } \\
\text { tude to work independently, to } \\
\text { perform representative func- } \\
\text { tions, to work in a group and } \\
\text { to carry out management } \\
\text { activities }\end{array}$ & $\begin{array}{l}\text { assessment of tasks } \\
\text { execution; } \\
\text { system of grouping; } \\
360 \text { degree approach; } \\
\text { group discussion }\end{array}$ & $\begin{array}{l}\text { Summary statement of } \\
\text { violations revealed } \\
\text { according to audit check }\end{array}$ \\
\hline \multicolumn{4}{|c|}{ 5. Audit of HR processes } \\
\hline 5.1. & $\begin{array}{l}\text { Review of workforce } \\
\text { planning, recruitment and } \\
\text { personnel screening }\end{array}$ & $\begin{array}{l}\text { Selection and analysis of } \\
\text { documents/reports } \\
\text { Analysis of objective } \\
\text { indices in terms of staff } \\
\text { size }\end{array}$ & $\begin{array}{l}\text { Analytical schedule of } \\
\text { workforce planning, } \\
\text { recruitment and } \\
\text { screening indices }\end{array}$ \\
\hline 5.2 & $\begin{array}{l}\text { Checking the system of labour } \\
\text { motivation and stimulation }\end{array}$ & $\begin{array}{l}\text { Questionnaire } \\
\text { interviewing managers } \\
\text { and individual HR } \\
\text { specialists, description of } \\
\text { business processes } \\
\text { Assessment of key } \\
\text { employees }\end{array}$ & Interview schedules \\
\hline \multicolumn{4}{|c|}{ 6. Audit of human resources capability } \\
\hline 6.1 & Verification of staffing level & $\begin{array}{l}\text { Analysis of objective } \\
\text { indices in terms of staff } \\
\text { size }\end{array}$ & $\begin{array}{l}\text { Analytical schedule of } \\
\text { staffing level in the } \\
\text { whole enterprise and } \\
\text { management levels, } \\
\text { employee turn over }\end{array}$ \\
\hline 6.2. & $\begin{array}{l}\text { Assessment of employee's } \\
\text { level of training compliance } \\
\text { with personnel occupational } \\
\text { standards and professional } \\
\text { competence }\end{array}$ & $\begin{array}{l}\text { Sum of scores approach } \\
\text { Monitoring the process of } \\
\text { key management } \\
\text { communications } \\
\text { (consultations, } \\
\text { inspections, meetings) }\end{array}$ & $\begin{array}{l}\text { Certificate of auditing } \\
\text { results }\end{array}$ \\
\hline
\end{tabular}




\begin{tabular}{|l|l|l|l|}
\hline 6.3. & $\begin{array}{l}\text { Assessment of key } \\
\text { employees } \\
\text { framework a personnel } \\
\text { and demographic of social } \\
\text { characteristics }\end{array}$ & $\begin{array}{l}\text { Analytic investigation of } \\
\text { objective indices in terms } \\
\text { of social and demographic } \\
\text { characteristics }\end{array}$ & $\begin{array}{l}\text { Summary statement of } \\
\text { violations revealed } \\
\text { according to audit check }\end{array}$ \\
\hline
\end{tabular}

Both separate sections and the entire audit plan can be agreed and discussed with the audited entity's management and labour collective representatives to improve HR audit efficiency and to coordinate audit procedures with the personnel work. Thus, when framing the personnel audit strategy it is necessary to find out the economic entity management's opinion regarding the factors being essential for the effective personnel policy implementation as well as possible problems and risks of managers' concern. At drawing up the personnel audit plan the criteria selected for assessing the personnel policy effectiveness should be discussed and, if possible, agreed with the responsible executives of the entity under audit.

\section{Conclusions}

Audit planning is iplemented in order to ensure proper attention to important aspects of auditing, timely diagnosis and resolution of possible problems, as well as the organization and quality of audit tasks. Personnel audit planning takes into account the audit assignment scope of work, rendering of auditor services provided in view of concluded contract terms and also considers the expected audit scope. The auditor's professional opinion is very important in audit activities planning in order to properly assess the audit risk and develop audit measures necessary to reduce this risk to a lower level. In view of the foregoing, the results of the audit appear to be as follows: planning the scope and type of services provided for the current period; budget expenditures; scheming the use of material, labor and financial resources.

Thus, planning plays an important role in personnel audit conducting since it helps the auditor to pay attention to important audit aspects; to identify and eliminate problems; to manage the task to make it more effective as well as to mitigate risks before work assignment. Submitting the audit plan helps to inform the persons responsible for corporate governance about significant issues identified in the process of audit and the auditors' report drawing up. The audited persons seeking publicity and transparency of reporting receive an understanding of the auditing process and the resources spent on it.

\section{References}

1. A. Susanto, International Business Management 10, 5523-5529 (2016)

2. A.A. Arens, J.K. Loebbecke, Auditing: an integrated approach (Prentice Hall, Englewood Cliffs, NJ, 1997)

3. B.R. Gaumnitz, T.R. Nunamaker, J.J. Surdick, M.F. Thomas, Journal of Accounting Research 20(II), 745-755 (1982)

4. G.S. Klychova, A.R. Zakirova, Z.R. Zakirov, G.R. Valieva, Asian Social Science 1111, 308-312 (2015)

5. G.S. Klychova, A.R. Zakirova, E.R. Kamilova, International Business Management 10, 5254 (2016)

6. G.S. Klychova, A.R. Zakirova, K.Z. Mukhamedzyanov, E.R. Sadrieva, A.S. Klychova, Journal of Engineering and Applied Sciences 12 (19), 4966-4973 (2017) 
7. G.S. Klychova, A.R. Zakirova, K.Z. Mukhamedzyanov, M.S. Faskhutdinova, Mediterranean Journal of Social Sciences 5-20, 220-224 (2014)

8. G.S. Klychova, B.G. Ziganshin, A.R. Zakirova, G.R. Valieva, A.S. Klychova, Journal of Engineering and Applied Sciences 12, 4958 (2017)

9. G.S. Klychova, L.I. Kulikova, L.M. Mavlieva, A.S. Klychova, Mediterranean Journal of Social Sciences 5-20, 205-209 (2014)

10. M. Noor Hisham Osman, S. Zaidah Turmin, H. Muhamad, R. Hussain, International Business Management 10, 3733-3738 (2016)

11. A.S. Mukhina, Asian Social Scienc. 11-8, 58-64 (2015)

12. H. Li-Jen, International Business Management 9, 1686-1697 (2015)

13. M. Deldoost, J.E. Wagner, International Business Management 10, 1192-1202 (2016)

14. M. Ramos, Journal of Accountancy http:/www.journalofaccountancy.com/Issues/2009/Dec/ 20091789.htm

15. Sohee Woo, Hyunji Lim, Asian Social Scienc. 11-18, 144-152 (2015)

16. A.Y. Sokolov, L.B. Sungatullina, Asian Social Scienc 11-11, 379-384 (2015)

17. E.N. Fakhretdinova, G.S. Klychova, A.S. Klychova, N.V. Antonova, Asian Social Science 11-11, 318 (2015)

18. V. Nazarova, International Business Management 9, 41-53 (2015)

19. Zaim Korsi, Alba Robert Dumi, Hava Mucollari, Mediterranean Journal of Social Sciences 4-10 (2013) 